Original Research Paper

\title{
Peningkatan Kapasitas Sumber Daya Manusia Tentang Mitigasi Bencana Desa Sekotong Tengah Menuju Desa Tangguh Bencana
} \author{
Nurmala Sari ${ }^{6}$, Gita Juhara ${ }^{6}$ \\ ${ }^{1}$ Pendidikan Biologi, FKIP Universitas Mataram, Indonesia. \\ ${ }^{2}$ Pendidikan Fisika, FKIP Universitas Mataram, Indonesia. \\ ${ }^{3}$ Pendidikan Bahasa Indonesia, FKIP Universitas Mataram, Indonesia. \\ ${ }^{4}$ Pendidikan Matematika, FKIP Universitas Mataram, Indonesia. \\ ${ }^{5}$ Pendidikan Bahasa Inggris, FKIP Universitas Mataram, Indonesia. \\ ${ }^{6}$ Pendidikan PPKN, FKIP Universitas Mataram, Indonesia.
}

I Gde Mertha ${ }^{*}$, Ummu Ashyfah', Lisdah Wati², Yudistira ${ }^{3}$, Ijmah ${ }^{3}$, Warni Larasati ${ }^{3}$, Umayrah $^{4}$, Ikhlas Zul Amal ${ }^{4}$, Baiq Peni Rahmawati ${ }^{5}$, Sofiah Rahmi Sumayani ${ }^{5}$, Laelatul Alya Istiana ${ }^{6}$,

https://doi.org/10.29303/jpmpi.v3i2.1343

Sitasi: Mertha, I. G., Ashyfah, U., Wati, L., Yudistira., Ijmah., Larasati, W., Umayrah., Amal, I. Z., Rahmawati, B. P., Sumayani, S. R., Istiana, L. A., Sari, N \& Juhara, G. (2022). Peningkatan Kapasitas Sumber Daya Manusia Tentang Mitigasi Bencana Desa Sekotong Tengah Menuju Desa Tangguh Bencana. Jurnal Pengabdian Magister Pendidikan IPA, 5(1)

\section{Article history}

Received: 11 Januari 2022

Revised: 01 Februari 2022

Accepted: 07 Februari 2022

*Corresponding Author: I Gde Mertha, University of Mataram, Mataram, Indonesia; Email:

gdemertha19@gmail.com
Abstrak: Bencana diartikan sebagai peristiwa atau rangkaian peristiwa yang mengancam dan menganggu kehidupan dan penghidupan masyarakat yang disebabkan oleh faktor alam dan faktor manusia sehingga mengakibatkan timbulnya korban jiwa, kerusakan lingkungan, kerugian harta benda, dan dampak psikologis (Perke BNPB No. 02 Tahun 2021). Banjir merupakan salah satu bencana yang sering terjadi di Indonesia, salah satunya di Desa Sekotong Tengah. Desa Sekotong Tengah merupakan salah satu desa yang ada di Kabupaten Lombok Barat, Provinsi Nusa Tenggara Barat. Permasalahan banjir yang terjadi di Desa Sekotong Tengah merupakan bencana musiman yang kerap terjadi setiap tahunnya pada musim hujan. Untuk itu, upaya yang perlu dilakukan dalam menanggulangi banjir adalah meminimalkan dampak/resiko yang ditimbulkan akibat bencana banjir atau yang disebut dengan mitigasi. Salah satu bentuk mitigasi yang dapat dilakukan untuk mengurangi dampak risiko banjir yaitu dilakukan penyuluhan dan sosialisasi serta ditindaklanjuti kerja bakti. Berdasarkan hasil penyuluhan bahwa sebagian besar masyarakat Sekotong Tengah masih belum memahami dampak banjir. Data banjir yang terjadi pada awal tahun 2021 merendam 13 dari 18 dusun di Desa Sekotong Tengah. Hal ini menunjukkan bahwa dampak bencana banjir yang terjadi di awal tahun 2021 di Desa Sekotong Tengah yaitu sebesar 72\%. Data tersebut menunjukkan sekotong 1 menjadi dusun yang paling tinggi terdampak banjir sampai dengan dusun mekar sari paling rendah. Berdasarkan hasil sosialisasi didapatkan bahwa sebagian masyarakat masih membuang sampah sembarangan di saluran drainase. Hasil pengamatan sebelum sosialisasi terhadap sampel sebanyak 14 KK di Dusun Sekotong II Desa Sekotong Tengah menunjukkan $10 \mathrm{KK}$ (71\%) yang membuang sampah sembarangan dan 4 KK (29\%) yang tidak membuang sampah sembarangan. Setelah dilakukan sosialisasi, mulai terlihat perubahan masyarakat tidak lagi membuang sampah sembarangan di saluran drainase yaitu sebanyak 8 KK (57\%) yang tidak membuang sampah sembarangan dan 6 KK (43\%) yang masih membuang sampah sembarangan. Hal ini dapat disimpulkan bahwa sosialisasi yang dilakukan cukup berhasil memberikan kesadaran kepada masyarakat untuk tidak membuang sampah sembarangan. Setelah kegiatan sosialisasi ditindaklanjuti dengan kegiatan kerja bakti membersihkan saluran drainase seperti selokan. Keterlibatan masyarakat dalam kegiatan ini tidak maksimal karena bersamaan dengan kesibukan masyarakat yang berkebun di pengunungan.

Kata kunci: Bencana Banjir, Peningkatan Sumber Daya Manusia, Mitigasi Bencana, Penyuluhan, Sosialisasi, Kerja Bakti 


\section{Pendahuluan}

Bencana diartikan sebagai peristiwa atau rangkaian peristiwa yang mengancam dan menganggu kehidupan dan penghidupan masyarakat yang disebabkan oleh faktor alam dan faktor manusia sehingga mengakibatkan timbulnya korban jiwa, kerusakan lingkungan, kerugian harta benda, dan dampak psikologis (Perke BNPB No. 02 Tahun 2021). Salah satu bencana yang sering terjadi di Indonesia adalah banjir. Menurut Somantri (2008) dalam Mardikaningsih, dkk (2017) Banjir adalah luapan atau genangan dari sungai atau badan air lainnya yang disebabkan oleh curah hujan yang berlebihan atau salju yang mencair atau dapat pula karena gelombang pasang yang membanjiri kebanyakan pada dataran banjir.

Desa Sekotong Tengah merupakan salah satu desa yang ada di Kabupaten Lombok Barat, Provinsi Nusa Tenggara Barat. Luas wilayah Desa Sekotong Tengah sebesar $\pm 4.536 .000 \mathrm{~m}^{2}$. Desa Sekotong Tengah terdiri dari 18 dusun dan 65 RT. Wilayah Desa Sekotong Tengah terletak pada ketinggian antara 0-1.000 meter di atas permukaan laut. Lahan di Desa Sekotong Tengah mempunyai tingkat kemiringan yang bervariasi. Curah hujan rata-rata sebesar $1.382 \mathrm{~mm}$ dengan jumlah hari hujan rata- rata 120 hari. Bulan basah 4-6 bulan, sedangkan bulan kering berkisar antara 6-7 bulan. Musim hujan dimulai pada bulan Oktober-November dan pada bulan April-Mei terjadi musim kemarau pada setiap tahunnya. Puncak curah hujan dicapai pada bulan Desember-Februari. Suhu udara rata-rata setiap hari berkisar $27,7{ }^{\circ} \mathrm{C}$, suhu minimum $23,2{ }^{\circ} \mathrm{C}$, dan suhu maksimum $32,4{ }^{0} \mathrm{C}$.

Permasalahan banjir yang terjadi di Desa Sekotong Tengah merupakan bencana musiman yang kerap terjadi setiap tahunnya pada musim hujan. Berdasarkan data terakhir korban banjir Desa Sekotong Tengah awal tahun 2021 dengan jumlah dusun terdampak 13 dusun antara lain, Sekotong 1, Sekotong 2, Tanjung Batu, Gunung Kosong, Karang
Lebah, Lendang Re, Telage Lebur Kebon, Suredadi, Telage Lebur Dese, Mekar Sari, Telage Lebur Loang Balok, Aik Tangi, dan Gunung Anyar. Dengan jumlah KK terdampak 1820 dan 5578 jiwa. Adapun dusun rawan banjir antara lain, Dusun Sekotong I, Dusun Sekotong II, Dusun Suredadi, Dusun Mekar Sari, dan Dusun Telaga Lebur Dese.

Salah satu penyebab terjadinya bencana banjir di Desa Sekotong Tengah diakibatkan karena terdapat dua sungai besar yang mengapit 10 dusun induk di wilayah dataran rendah, kemudian disertai air laut pasang ketika musim hujan maka terjadilah banjir yang kapasitasnya besar dengan durasi yang sangat lama seperti yang terjadi pada awal tahun 2021 dan menyebabkan beberapa fasilitas umum, seperti sekolah, masjid, pasar, dan fasilitas lainnya terendam dan mengalami kerusakan. Air laut pasang biasanya terjadi pada pertengahan bulan dan akibatnya air masuk pada pemukiman rumah warga, namun durasinya tidak terlalu lama. Selain itu, banjir juga ditimbulkan karena masih banyaknya masyarakat yang membuang sampah sembarangan di saluran drainase. Hal ini menyebabkan saluran drainase tersumbat dan mengakibatkan air meluap merendam rumah warga saat musim hujan.

Menurut Maryono (dalam Budiarti, dkk. 2017) Pengendalian bencana banjir akan lebih efektif jika melibatkan masyarakat karena masyarakat adalah pihak yang pertama kali berhadapan langsung dengan resiko bencana, sekaligus proses pembelajaran kepada masyarakat tentang banjir dan pentingnya konservasi lahan untuk pengendalian banjir. Jika terjadi bencana, masyarakat yang tinggal di kawasan rawan akan menjadi pihak yang paling dirugikan. Sesuai UU Nomor 24 Tahun 2007 tentang Penanggulangan Bencana mengamanatkan untuk melindungi masyarakat dari ancaman bencana. Salah satu strategi untuk mewujudkan hal tersebut adalah melalui pengembangan masyarakat tangguh bencana sebagai upaya pengurangan risiko bencana 
berbasis komunitas (PRBBK). Suatu daerah sulit dikatakan bebas dari bencana banjir karena kemungkinan terjadi debit yang sama atau bahkan melampaui debit akan selalu ada dalam setiap tahunnya, sehingga upaya yang perlu dilakukan dalam menanggulangi banjir adalah meminimalkan dampak/resiko yang ditimbulkan akibat bencana banjir atau yang disebut dengan mitigasi. Salah satu bentuk mitigasi yang dapat dilakukan untuk meminimalisir dampak risiko banjir yaitu dilakukan secara sosialisasi atau melalui mitigasi non struktural.

Berdasarkan pemaparan di atas, maka dalam membentuk desa Tangguh bencana diperlukan peningkatan kapasitas sumber daya manusia tentang mitigasi melalui sosialisasi dan penyuluhan bencana banjir yang ditindaklanjuti kegiatan kerja bakti bersama masyarakat Desa Sekotong Tengah.

\section{Metode}

\section{Waktu dan Tempat Pelaksanaan}

Kegiatan KKN yang dilakukan oleh Mahasiswa ini dilaksanakan dalam dua tahap kegiatan, yaitu penyuluhan dan sosialisasi yang diikuti kegiatan kerja bakti. Kegiatan penyuluhan bencana banjir dilaksanakan pada hari Rabu, 15 Desember 2021 pukul 09:0012:00 WITA di Aula kantor Desa Sekotong Tengah. Sedangkan kegiatan sosialisasi dilaksanakan dengan mengunjungi rumahrumah warga. Kegiatan ini berlangsung sebanyak 2 kali, yang dirangkaikan dengan kegiatan kerja bakti membersihkan saluran drainase bersama warga.

\section{Alat dan Bahan}

Alat yang diperlukan untuk kegiatan penyuluhan adalah kamera foto, kamera video, laptop beserta LCD, sound system, microphone, meja dan kursi . Bahan yang yang diperlukan yaitu buku registrasi peserta penyuluhan dan pulpen. Sedangkan untuk kegiatan sosialisasi yang dirangkaikan dengan kegiatan kerja bakti, alat yang diperlukan yaitu kamera foto dan perekam suara. Bahan yang diperlukan yaitu kantung plastik (trash bag), gerobak sorong, tempat sampah, dan sapu lidi.

\section{Pelaksanaan Penyuluhan}

Penyuluhan terkait bencana banjir pada 15 Desember 2021 ini sasarannya yaitu kepala dusun, relawan dan masyarakat setempat serta bekerjasama dengan mitra desa terkait mitigasi dan pihak BPBD Lombok Barat sebagai pemateri dalam kegiatan penyuluhan. Kegiatan ini diikuti sebanyak 30 peserta. Dalam penyuluhan ini akan diberikan materi yang terkait dengan: mitigasi bencana banjir meliputi apa itu mitigasi, 4 hal yang penting dalam mitigasi, tujuan mitigasi, macammacam mitigasi, penyebab terjadinya banjir, cara yang harus dilakukan sebelum terjadinya banjir (penanggulangan), saat terjadinya banjir, dan setelah terjadinya banjir.

\section{Pelaksanaan Sosialisasi dan Kerja Bakti}

Sosialisasi bencana banjir merupakan kegiatan lanjutan dari penyuluhan yang dilaksanakan oleh Mahasiswa KKN dengan mengunjungi rumah-rumah warga. Pada saat sosialisasi, warga cukup antusias dalam mendengarkan dan menanggapi. Sampel warga yang digunakan dalam kegiatan ini sebanyak 14 KK dari Dusun Sekotong II. Materi sosialisasi yang disampaikan lebih menekankan pada dampak yang ditimbulkan ketika masyarakat membuang sampah sembarangan. Tujuan dari kegiatan sosialisasi yaitu memberikan pemahaman kepada masyarakat terhadap dampak membuang sampah sembarangan yang dapat memicu terjadinya luapan air sungai ke pemukiman.

Setelah kegiatan sosialisasi, ditindaklanjuti dengan kegiatan kerja bakti dengan membersihkan saluran drainase bersama warga sekitar.

\section{Hasil dan Pembahasan}

\section{Penyuluhan Mitigasi Bencana Banjir}


Kegiatan penyuluhan bencana banjir yang dilakukan oleh Mahasiswa KKN Desa Sekotong Tengah ini berkolaborasi dengan BPBD Lombok Barat serta tim penanggulangan bencana desa. Tujuan dari kegiatan ini yaitu untuk membangun pemahaman masyarakat terkait mengurangi resiko banjir. Salah satu materi yang disampaikan oleh BPBD Lombok Barat, diantaranya apa yang harus dilakukan sebelum bencana banjir terjadi, pada saat terjadinya banjir, dan setelah banjir terjadi. Selain upaya peningkatan pengetahuan masyarakat terkait bencana banjir, pengurangan resiko bencana juga dilaksanakan dengan adanya pemetaan daerah rawan bencana. Pemetaan rawan bencana bertujuan memberikan gambaran umum dusun yang digunakan dalam penetapan terkait upaya pengurangan resiko dalam jangka panjang.

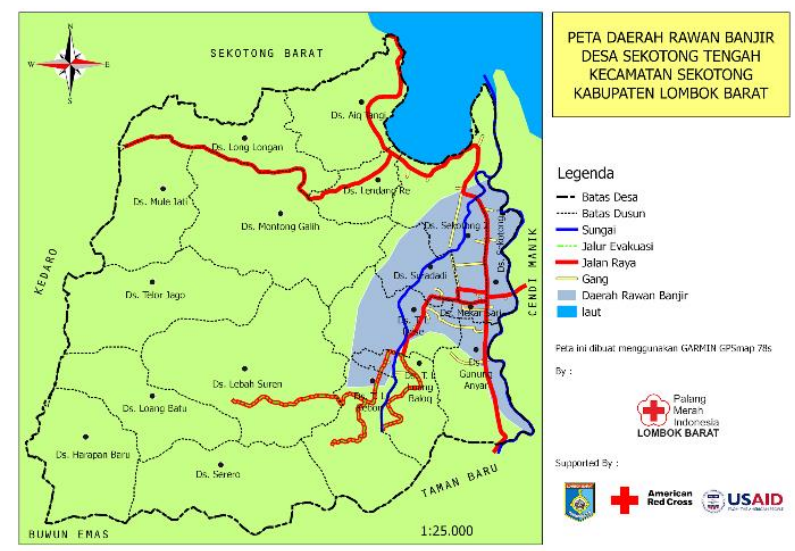

Gambar 1. Peta Daerah Rawan Banjir (Peta Bencana) Desa Sekotong Tengah (sumber:

https://www.bankdatadesaku.com/2021/07/peta-daerahrawan-banjir-desa-sekotong.html)

Berdasarkan hasil dalam kegiatan penyuluhan bahwa sebagian besar masyarakat Sekotong Tengah masih belum memahami dampak banjir, sehingga Sekretaris Desa Sekotong Tengah berharap agar Mahasiswa KKN dapat memanfaatkan ilmu yang di dapat di bangku perkuliahan dengan memberikan pemahaman terkait dampak banjir sehingga meningkatkan kesiapsiagaan masyarakat menghadapi bencana sedini mungkin yang bisa mengurangi resiko dari bencana banjir itu sendiri. Dalam kegiatan ini, salah satu peserta penyuluhan menyatakan perlunya menyelamatkan diri sendiri sebelum menyelamatkan orang lain. Hal ini berkaitan dengan meningkatkan ketangguhan dalam diri sendiri di dalam menghadapi bencana banjir.

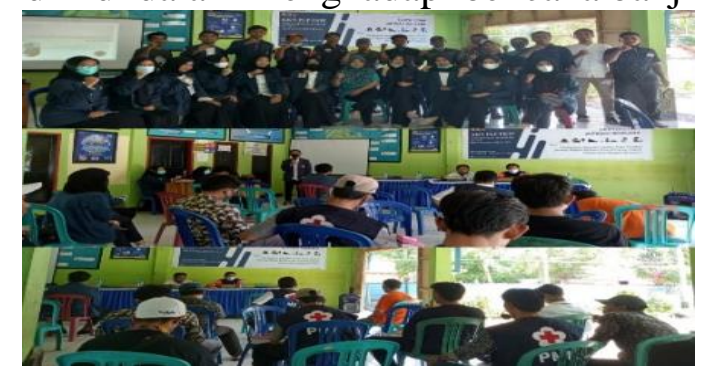

Gambar 2. Kegiatan Penyuluhan Mitigasi Bencana

(Sumber: Dokumentasi Ikhlas Zul Amal)

Berikut data korban banjir Desa Sekotong Tengah Kecamatan Sekotong Kabupaten Lombok Barat pada awal tahun 2021:

\begin{tabular}{|l|l|l|l|}
\hline No & Nama Dusun & $\begin{array}{l}\text { Jumlah } \\
\text { KK }\end{array}$ & $\begin{array}{l}\text { Jumlah } \\
\text { Jiwa }\end{array}$ \\
\hline 1 & Sekotong I & 201 & 744 \\
\hline 2 & Sekotong II & 155 & 455 \\
\hline 3 & Tanjung Batu & 108 & 338 \\
\hline 4 & Gunung Kosong & 110 & 366 \\
\hline 5 & Karang Lebah & 102 & 320 \\
\hline 6 & Lendang Re & 94 & 324 \\
\hline 7 & Telage Lebur Kebon & 130 & 511 \\
\hline 8 & Suredadi & 101 & 428 \\
\hline 9 & Telage Lebur Dese & 289 & 548 \\
\hline 10 & Mekar Sari & 97 & 215 \\
\hline 11 & $\begin{array}{l}\text { Telage Lebur Loang } \\
\text { Balok }\end{array}$ & 135 & 470 \\
\hline 12 & Aik Tangi & 194 & 506 \\
\hline
\end{tabular}




\begin{tabular}{|l|l|l|l|}
\hline 13 & Gunung Anyar & 104 & 353 \\
\hline JUMLAH & $\mathbf{1 8 2 0}$ & $\mathbf{5 5 7 8}$ \\
\hline
\end{tabular}

Data Korban Banjir Desa

Sekotong Tengah Kecamatan

Sekotong Kabupaten Lombok

Barat 2021

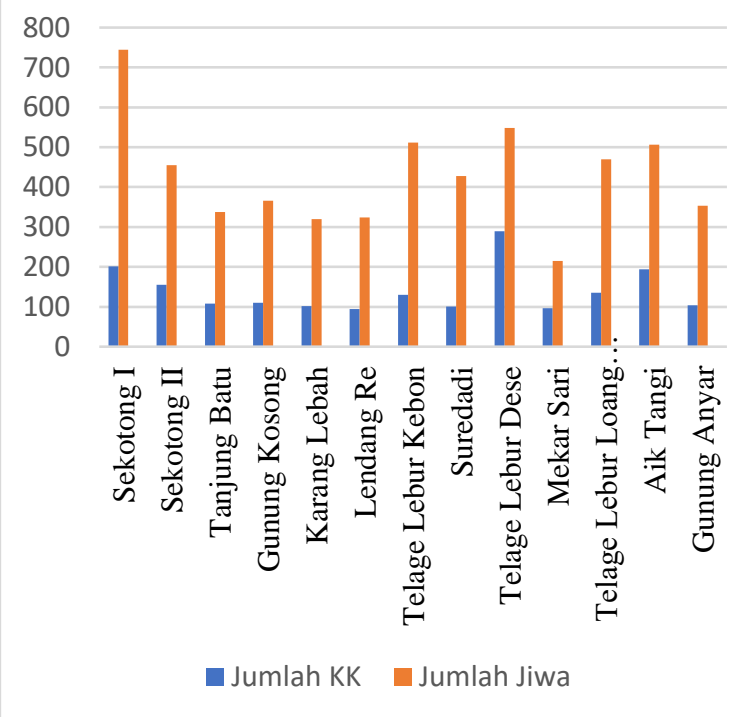

Grafik 1. Korban Banjir Desa Sekotong Tengah

Kecamatan Sekotong Kabupaten Lombok Barat 2021

Bencana banjir yang terjadi pada awal tahun 2021 merendam 13 dari 18 dusun di Desa Sekotong Tengah. Grafik di atas menunjukkan bahwa dampak bencana banjir yang terjadi di awal tahun 2021 di Desa Sekotong Tengah yaitu sebesar $72 \%$ Hal ini menunjukkan bahwa bencana banjir tersebut menimbulkan dampak yang sangat besar. Data diatas menunjukkan sekotong 1 menjadi dusun yang paling tinggi terdampak banjir sampai dengan dusun mekar sari paling rendah.

Adapun penanganan yang dilakukan pemerintah desa Sekotong untuk mengurangi resiko dari bencana banjir diantaranya pembuatan talud, pembuatan irigasi, dan membersihkan saluran irigasi yang sudah ada. Kedua untuk banjir rob, Pemdes sudah melakukan berbagai macam upaya diantaranya penanaman mangrove, talud, dan lain sebagaianya. Untuk mangrove sendiri, selain sebagai penghalang air rob, mangrove juga bisa menetralisir pencemaran yang diakibatkan oleh limbah-limbah bahan kimia, seperti merkuri dan logam berat lainnya.

\section{Sosialisasi Bencana Banjir dan Kerja Bakti}

Kegiatan sosialisasi bencana banjir yang dilakukan oleh Mahasiswa KKN merupakan kelanjutan kegiatan penyuluhan yang sebelumnya sudah dilakukan. Kegiatan ini dilakukan oleh Mahasiswa KKN dengan mengunjungi rumah-rumah warga secara langsung. Kegiatan sosialisasi bertujuan untuk memberikan pemahaman kepada masyarakat terkait dampak banjir. Pemberian pemahaman ini diantaranya dengan meningkatkan kesadaran masyarakat terhadap dampak membuang sampah sembarangan. Berdasarkan hasil pengamatan langsung, sebagian masyarakat masih membuang sampah sembarangan di saluran drainase. Hal ini mengakibatkan saluran drainase tersumbat, sehingga ketika musim hujan, air meluap dan menggenangi rumah-rumah warga.

Dari hasil diskusi saat sosialisasi, sebagian masyarakat memberi alasan bahwa Desa Sekotong Tengah belum memiliki TPS (Tempat Pembuangan Sampah Sementara). Sehingga masyarakat mengambil alternatif membuang sampah di kebun, di saluran, dan dilakukan dengan cara membakar sampah .

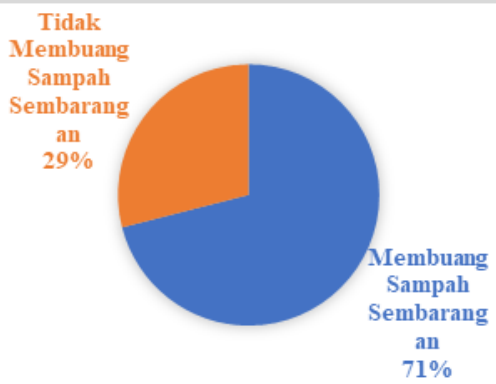

Gambar 3. Perbandingan warga Desa Sekotong yang membuang sampah sembarangan dan warga yang tidak membuang sampah sembarangan sebelum sosialisasi

Gambar 2 menunjukkan bahwa kesadaran masyarakat untuk membuang 
sampah pada tempatnya sangat rendah. Hasil pengamatan sampel terhadap $14 \mathrm{KK}$ di Dusun Sekotong II Desa Sekotong Tengah menunjukkan $10 \mathrm{KK}(71 \%)$ yang membuang sampah sembarangan dan 4 KK (29\%) yang tidak membuang sampah sembarangan.

Setelah dilakukan sosialisasi, mulai terlihat perubahan masyarakat tidak lagi membuang sampah sembarangan di saluran drainase. Terbukti pada gambar 3 menunjukkan 6 KK (43\%) yang masih membuang sampah sembarangan dan $8 \mathrm{KK}(57 \%)$ yang tidak membuang sampah sembarangan. Hal ini dapat disimpulkan bahwa sosialisasi yang dilakukan cukup berhasil memberikan kesadaran kepada masyarakat untuk tidak membuang sampah sembarangan.

Gambar 4. Perbandingan warga Desa Sekotong yang membuang sampah sembarangan dan warga yang tidak membuang sampah sembarangan setelah sosialisasi

Setelah kegiatan sosialisasi ditindaklanjuti dengan kegiatan kerja bakti membersihkan saluran drainase seperti selokan. Kegiatan ini bertujuan untuk membersihkan sampah, sehingga saluran drainase tidak tersumbat ketika musim hujan. Kegiatan ini dilakukan oleh Mahasiswa KKN bersama dengan warga masyarakat yang ikut berpartisipasi dalam membersihkan lingkungan sekitar. Keterlibatan masyarakat dalam kegiatan ini tidak maksimal karena bersamaan dengan kesibukan masyarakat yang berkebun di pengunungan.
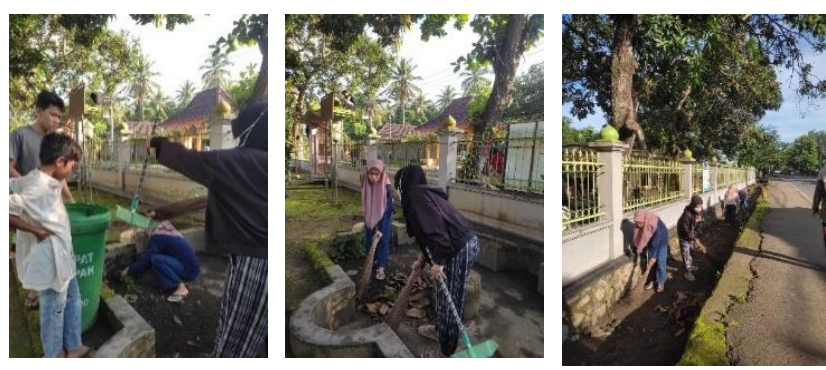

Gambar 5. Kegiatan kerja bakti membersihkan saluran drainase bersama masyarakat

\section{Kesimpulan}

Berdasarkan hasil penyuluhan dan sosialisasi dapat disimpulkan sebagai berikut: (1) Sebagian besar masyarakat Sekotong Tengah masih belum memahami dampak banjir, (2) Bencana banjir yang terjadi pada awal tahun 2021 menimbulkan dampak yang sangat besar yaitu sebesar 72\%, (3) Sebelum sosialisasi, kesadaran masyarakat untuk membuang sampah pada tempatnya sangat rendah yaitu sebesar $71 \%$ (4) Setelah dilakukan sosialisasi, mulai terlihat perubahan masyarakat tidak lagi membuang sampah sembarangan di saluran drainase sebesar 57\%.

\section{Ucapan Terima Kasih}

Terima kasih kepada Desa Sekotong Tengah yang telah memberikan pengalaman kepada Mahasiswa KKN PLP Universitas Mataram, serta pihak-pihak yang telah membantu keberhasilan jalannya Proker KKN Mahasiswa, khususnya kepada pihak-pihak yang bergerak dalam penanggulangan bencana banjir desa Sekotong Tengah. Tidak lupa pula, ucapan terima kasih kepada Drs. I Gde Mertha, M.Si. selaku Dosen Pembimbing Lapangan (DPL) yang mengarahkan mahasiswa dalam menyelesaikan artikel ini, serta teman-teman KKN.

\section{Daftar Pustaka}

Budiarti, Wiwin, Evi Gravitiani dan Mujiyo. 2017. Upaya Mitigasi Banjir di Sub DAS Samin Melalui Pengembangan 
Masyarakat Tangguh Bencana. Jurnal

Teknologi Lingkungan. 18 (2): 241-250.

Imansyah, Nur. 2021. BPBD NTB Sebut Banjir

Terparah Terjadi di Lombok Barat.

Diakses Dari sumber https://www.antaranews.com/berita/2567

433/bpbd-ntb-sebut-banjir-terparah-

terjadi-di-lombok-barat. Pada tanggal 31

Desember 2021 pukul 10:41 WITA.

Mardikaningsih, Sri Muliani, Chatarina

Muryani, dan Setya Nugraha. 2017.

Studi Kerentanan dan Arahan Mitigasi

Bencana Banjir di Kecamatan Puring

Kabupaten Kebumen Tahun 2016.

Jurnal GeoEco. 3 (2): 157-163.

Suwaryo, P.A.W., \& Yuwono, P. (2017).

Faktor-Faktor Yang Mempengaruhi

Tingkat Pengetahuan Masyarakat Dalam

Mitigasi Bencana Alam Tanah Longsor.

URECOL, 305-314.

Umar, Iswandi dan Indang Dewatab. 2018.

Arahan Kebijakan Mitigasi Pada Zona Rawan Banjir Kabupaten Limapuluh Kota, Provinsi Sumatera Barat. Jurnal Pengelolaan Sumberdaya Alam dan Lingkungan. 8 (2): 251-257. 